\title{
Analysis on the Innovation of Power Marketing Management in Power Supply Enterprises
}

\author{
Tong Sijia, Jing Hejia, Bai Weiwei, Zhu Hongpu, Yang Chunyu, and Feng Wei
}

State Grid Heilongjiang Electric Power Co., Ltd. Hegang power supply company, Hegang City, Heilongjiang, China

Keywords: power supply companies; power marketing management; innovation

\begin{abstract}
With the improvement of people's quality of life, electricity plays an important role in people's daily life and work, and people's demand for electricity is gradually increasing. The power supply enterprises must not only deliver safe and qualified power, but also innovate power marketing management, formulate a scientific marketing strategy, improve service quality, and satisfy the needs of the masses.
\end{abstract}

\section{Introduction}

The main role of power supply companies is to provide users with high-quality power products. In the past few years, China's emphasis on power products is not very high, and neither funding nor policies support it. With the continuous development of the economy, joint ventures and private power supply companies have emerged. How to emerge from such a large number of enterprises requires power supply companies to strengthen their marketing concepts, integrate relevant business activities, and launch-related activities to promote rapid business development.

\section{Overview of Power Marketing Management for Power Supply Companies}

In the development of market economy, electricity marketing is an important product. In previous economic planning, the power supply companies were within the scope of state-owned assets and did not have to carry out marketing activities. The power marketing activities of the power supply enterprises are based on users, meet the various requirements of users as much as possible, provide high-quality services and innovate marketing concepts, and provide users with high-security power products. Providing quality services, increasing market share, and improving the economic efficiency of enterprises are the goals of the power company's power marketing management. In order to accomplish the target task, the power supply company must train the electric sales personnel and optimize the power marketing management system.

\section{Characteristics of Power Marketing}

\subsection{Monopoly.}

With the support of distribution networks, electricity can be delivered and sold. Combined with the needs of users, power supply companies use transmission and distribution networks to transmit power to users. Transmission and distribution networks are sales routes for power marketing. In the national grid project, the transmission and distribution network is the core part of it. The government plans and manages it in a unified way. Private companies are forbidden to create them privately. This power marketing has a certain degree of monopoly. In order to reduce the occurrence of vicious competition and increase the economic efficiency of power supply enterprises, under normal circumstances, only one power supply enterprise can be established in a region, which can reduce the competitiveness among enterprises to some extent. This phenomenon only exists in independent power generation companies. The use of fair competition among various power supply companies to get the right to use the power grid, and same as the bidding model, low price, high-efficiency power supply companies can win the power supply qualification, power supply companies with low 
efficiency and poor environment will eventually be eliminated. However, as China has launched a large user power supply technology, and has an impact on the market competition, to a certain extent, reducing the monopoly of power marketing.

\subsection{Exclusivity.}

There is a significant gap between the power resources and other resources, and the preservation time of the power resources is not very long. The production, transmission, supply, and application are all completed quickly. The production and consumption are in a state of balance, which allows the power marketing to have exclusivity features. Because of the long distance, there is a problem of line consumption in the transmission process, resulting in serious waste of resources, for which most of the power supply companies have provided electricity services around them, due to the constraints of technical conditions, direct transactions with users cannot be conducted. Within the specified scope, power supply companies need to use fair competition to win power supply qualifications, thereby providing more users with electricity services. In order to ensure the normal operation of the power supply companies, maintain the continuous supply of electricity and strengthen its stability, and reduce the harm caused by the competition, it is necessary to create a power supply company within the scope of marketing. Electricity cannot be stored for a long time and can only be sold through designated transmission and distribution networks. Once there is no transmission and distribution network, electricity cannot be operated normally. This is also a key factor in the exclusiveness of electricity marketing.

\subsection{Fixed.}

The value of a commodity is weighed according to price, and the supply and demand relationship between the two can be clearly seen. Electricity is the precondition for sustaining the rapid development of the national economy. It has a direct impact on the stable development of society and its role is enormous. Therefore, the state has strictly controlled the price of electricity, and it is strictly forbidden for power companies to change the price of electricity at will. In the process of power marketing management, power supply companies must combine their own production characteristics and market requirements, and reasonably give the price of electricity, within the acceptable scope of the power supply company. However, the electricity market staff will classify it according to the level of the price, settle based on the price, and finally specify the price of the electricity, not directly determined by the power supply company. In addition, some local price bureaus and the National Development and Reform Commission have imposed restrictions on the price of electricity terminals sales, which has caused the marketing model of power supply companies to be limited and cannot complete the sales promotion tasks through the price.

\section{Status Quo of Power Marketing Management in Power Supply Enterprises}

Nowadays, in the power industry, a good power marketing management system can not only improve the competitiveness of enterprises, promote the healthy development of enterprises, but also rely on various aspects to reform the power marketing management. Combining with the current situation of power supply management in power supply companies, there are still some problems that have a serious impact on the rationality and standardization of the entire power marketing market.

\subsection{Relatively lagged management mode.}

If any enterprise wants to have good development, it must actively introduce outstanding talents. Nowadays, there are relatively few talents for marketing professionals in power companies, and the importance attached to the formation of professional marketing teams is not enough. Many employees do not learn this profession. In daily work, they cannot combine problems to choose effective solutions, leading to marketing management to be in a backward state for a long time. In addition, the company attaches too much importance to economic efficiency and is relatively neglected in the introduction of innovative marketing management techniques and talents. Therefore, the power marketing management mode of power supply companies is lagging behind, and to a large 
extent, it restricts the development of electric power companies.

\subsection{Low market insight.}

In the electric power enterprise economy, users' electricity consumption is the key issue. How to occupy the main position in the resident market to promote the economic development of electric power companies is a key issue for improving the efficiency of marketing work. China's electric power companies do not attach great importance to market development trends, have low insights and cannot accurately judge potential markets. Therefore, it is necessary to improve the marketing model and method in combination with the consumer level of different levels of consumers in order to obtain the majority of users. In addition, the power companies lack a sound management system, poor service concept, and lack of a sound emergency management system. Once severe weather is encountered, it will affect the normal power supply of the power companies. to a large extent. This have no effect on the healthy development of power companies.

\subsection{Low information operation capability.}

Digital network technology is an important product in the process of social development, which provides opportunities for the development of enterprises and also increases the difficulty of enterprise management. In order to speed up work efficiency, power companies often apply digital information technologies to power marketing, such as electricity fee records, customer information, and payment systems. If employees leak information, they will cause serious losses to the company. At the same time, the network platform will also be subject to security threats. If a hacker enters, the entire system will be paralyzed, which will affect the normal operation of the power companies and cannot provide people with power services.

\subsection{Relatively intense Price competition}

In the process of power reform, the monopoly of power supply companies was gradually broken down. However, most of the power markets were caused by their own reasons, and even some companies' market share rose to $100 \%$. With the continuous emergence of new energy sources, some innovative energy sources have gradually entered people's lives, such as solar energy and natural gas. This has greatly limited the development of the electricity market and exacerbated the competitiveness of the energy market. People will choose more affordable new energy through comparison, and the price competition is relatively fierce.

\subsection{Lack of a sound management structure.}

At this stage, there are some deficiencies in the management structure of power supply companies. The main reasons are the lack of a sound management structure, the lack of a sound pre-sales and after-sales service system, and there are major problems with the management system and supervisory system, and it is impossible to maximize the effectiveness of management. Combined with the actual situation, many power supply companies did not add a specialized marketing department, even if some power supply enterprises added this department, they did not integrate the market department and the after-sales department, making the power marketing activities lack scientific and rational. In addition, the power supply companies did not receive support and guidance from the relevant departments in the later development process, so these unreasonable phenomena hampered the development of power supply companies.

\section{The Importance of Power Marketing Management Innovation in Power Supply Enterprises}

\subsection{Improve the economic efficiency of enterprises.}

If the power supply companies want to improve the economic efficiency, they must innovate the power marketing. This is also the key factor for power supply companies to maintain their market position. Service marketing is the main body of power marketing. using high-quality electric power service to improve user satisfaction and improve the image of the power supply company in the user's mind. Therefore, innovating power services and improving service quality are the main purposes of 
current power marketing management. At the same time, intensifying the innovation of power supply services can ensure the reliability and security of power supply to some extent, allowing users to enjoy high-quality services, satisfying users' demands for electricity as much as possible, and improving the credibility of the company.

\subsection{Improve enterprise management.}

Traditional power marketing management methods can no longer meet the current power market standards, power supply companies need to increase innovation and find power marketing strategies that can promote the rapid development of the company. Scientific and effective power marketing management strategies can not only bring high profits for enterprises, but also improve the level of corporate management, so that the power marketing process becomes standardized, rationalized, and avoid all types of hidden dangers during the operation, do emergency work, and promote rapid and good development of companies.

\subsection{Strengthen the standardized management of management personnel.}

In order to make the power marketing management work toward rationalization and standardization, companies must increase the supervision of their employees. First, adding the "advanced worker" floating flag. The voting method was chosen to encourage the marketing staff to always adhere to the people-oriented service concept, to master the knowledge of marketing management, and to accumulate experience and lessons in the daily marketing work, to stimulate the staff's innovative thinking and enthusiasm for work, to increase their sense of responsibility, and then improve the overall quality and moral level of employees. Secondly, install a report box to allow more consumers to participate in the supervision work, find work problems in a timely manner, comfort the feelings of consumers, and at the same time allow consumers to feel the high-quality service and unremitting efforts of the company. Complete the goal of steady growth of the electric power enterprise economy.

\section{Innovative Methods for Power Marketing Management of Power Supply Enterprises}

\subsection{Innovate marketing concepts.}

If power supply companies want to reform their power marketing strategies, the first thing to do is to innovate the power marketing concept, improve the quality of the power marketing staff, and let each of them have an innovative marketing concept to meet the changing requirements of the market. In the power marketing work, it is necessary to strengthen the internal personnel's competition ideas, have an optimistic and positive attitude, fully display the subjective initiative, eliminate old employees who do not have responsibility, actively introduce outstanding electric power marketing personnel, and innovate the marketing concept together. And in conjunction with market requirements, a reasonable marketing plan is formulated.

\subsection{Improve service quality.}

The continuous development of a modern economy has, to some extent, improved people's quality of life and spending power. People have put forward higher standards for power services. In order for power supply companies to win the support and trust of people, it is necessary to continuously improve the quality of power services, establish a good image of brand services, and strengthen the core competitiveness of enterprises. Therefore, power supply companies must reasonably develop service standards, innovate service models, and provide users with high-quality service models.

\subsection{Increase the innovation of management mechanism.}

In order to meet the current social development trend, the power supply companies need to improve the internal management mechanism, increase the innovation of the internal management organization structure, and conduct an orderly marketing and research and development of the power market. Power supply companies should formulate more detailed management mechanisms, conduct in-depth explorations of the overall situation, and make unified arrangements to create a sound user 
management mechanism under the standard service structure, stimulate potential user resources, add additional user service centers, and more cooperate with large enterprises.

\subsection{Innovate marketing technology strategy.}

New science and technology are prerequisites for the promotion of high-quality electric power services. Power supply companies must improve the power system, call center system, power distribution geographic information system, and user service management system to facilitate timely feedback on the needs and issues of late-stage users and collect relevant data, formulate a reasonable marketing strategy to effectively control and manage the entire power marketing process. At the same time, we will increase the management of information system security, raise staff awareness of safety risk responsibilities, constantly monitor and track information systems, develop risk warning and control mechanisms, and lay a solid foundation for the safety of electric power marketing.

\section{Development Prospects of Power Marketing Management}

\subsection{Put specialized basic management into place.}

Electric power companies need to regularly make each business hall work summary, point out the problems in the work, and organize the key contents so as to formulate a detailed annual plan. The creation of a marketing short-board library and a key work library makes annual work based on the idea of power marketing. Power supply companies should attach great importance to the power marketing work, gather all the power, check the basic marketing management system, facilitate the inspection of the user's power consumption and nature, organize the user data, and implement the annual marketing work of the power supply companies.

\subsection{Clear assessment direction.}

According to the current actual situation, the line loss rate has always been a problem that the power supply company attaches great importance to. The staff has no clear answer to the cause of the abnormality, so it has made it more difficult to handle the problem. In this regard, the degree of utilization of indicators for assessment should be strengthened, and the line loss rate should be tracked with the results of the final study.

\section{Conclusion}

To sum up, with the rapid development of the market economy, there are more development opportunities for the power supply enterprises. Innovating the power marketing management of the power supply companies can promote the development process of the enterprises to some extent and increase the economic benefits of the enterprises. In the process of development, power supply companies must not only have long-term development goals, but also have the support and assistance of the country, establish sound marketing management strategies, and rationally formulate marketing plans in accordance with current market trends to increase their share of the electricity market. At the same time, the power supply companies must also ensure that the quality of the power products is reasonable, understand the needs of users in depth, and divide users. In addition, they should intensify the innovation of the price mechanism and continue to introduce new types of electric power technologies to provide people with better quality electric power services and improve their economic strength.

\section{References}

[1] Anni Liu. On the Characteristics and Role of Power Marketing [J]. Enterprise Technology Development, 2013, (20): 46-47.

[2] Qinglian Ma. On the Innovation and Development of Electric Power Marketing Management [J]. China Science and Technology Investment, 2013, (z2): 215-216. 
[3] Hui Wang. Researching the Overall Innovation of Power Marketing Management for Power Supply Enterprises[J]. Science \& Technology and Enterprises, 2016, (4):78-79.

[4] Bo Wu, Huailin Zhang. Research on the Ways to Strengthen the Power Marketing Management of Power Supply Enterprises[J]. Science and Technology Innovation Review, 2014, (17): 167-168.

[5] Dong Liu. Analysis of Power Marketing of Power Supply Enterprises under New Situation [J]. Chinese Market, 2015, (19): 92-93.

[6] Zhaoguang Zhang. Discussion on the Defects and Improvement Measures of Power Marketing Management in Power Supply Enterprises[J]. China Hi-Tech Enterprise, 2015, (5):175-176.

[7] Chunyan Zhang. Analysis of Power Marketing Management Strategy and Implementation Measures of Power Supply Enterprises [J]. Science and Technology Economic Market, 2014, (12): 42-43.

[8] Chunyu Li. A Brief Discussion on the Role of Marketing Strategies and Quality Services in the Power Market[J]. Modern Economic Information, 2012, (6):114-115.

[9] Jifeng Wang. Current Situation and Suggestions of Power Marketing Management of Power Supply Enterprises [J]. New Technologies and Products in China, 2010, (8): 216-217. 